\title{
Circular Thinking: The Yamanote Line on Film
}

The Yamanote line encloses the landscape of central Tokyo, a landscape that takes on the kinetic qualities of film imagery when seen through the windows of a moving train. In many ways, the Yamanote line on film encapsulates the cinema's treatment of Tokyo. The line features frequently in films set in the city; how could it be otherwise, given its centrality to everyday life in the capital? Domestic and foreign productions alike recognise the inevitability of using the Yamanote line to move protagonists around or through Tokyo; the protagonists of films such as Train Man (Densha otoko, Murakami Shosuke, Tōhō, 2005) and Lost in Translation (Sofia Coppola, Focus Features, 2003) connect through a series of unnamed train lines in which the invested viewer can spot the Yamanote on their way to work or tourist sights. In films which highlight the Yamanote line in particular, such as Hou HsiaoHsien's Café Lumière (Kōhi jikō, Shōchiku, 2005) and Hanadō Junji’s 26 Years Diary (Anata o wasurenai, Sony Pictures, 2007), specific characteristics of the line are used to enhance plot points and develop characters. Analysing these two films, this article asks; what can we learn from 'thinking from the Yamanote' on film?

As Yuriko Furuhata argues in her work on Japanese cinema's fukeiron (landscape theory), landscape on film is political (2013). The implications of casting landscape as a kind of character are clearest in the experimental fukeiron films of the late 1960s and 1970s. The suturing of landscape into the smoother mise en scène common to the commercial feature film necessitates closer analysis in order to fully grasp the affect of bringing urban landscape to the viewer's attention in the way Hou and Hanado do. We must also question why directors such as these two choose to emphasize the setting of the Yamanote line specifically. Circling central Tokyo, the 
line passes through a diverse range of spaces blessed or blighted by particular social issues. Developing fukeiron landscape theory into the urban setting of contemporary central Tokyo, I suggest that foregrounding the Yamanote line on film allows filmmakers to visually address certain key political issues in contemporary Japan.

\section{Trains on Film}

Since its beginnings, cinema has been intimately connected with the railway; in fact, film historians often cite the widespread development of railway systems as a major motivating factor in the invention of cinema itself. As the view from a train window mirrors the kinetic experience of the cinema (Carlin 2007; Kirby 1997: 42-48; Schivelbusch 1986: 160), the popularization of train travel can be understood to have made the subsequent development of film technologies imaginable to a mass public. Both film and railway technologies have become symbolic of the rapid modernization of the late nineteenth and early twentieth centuries. It is no surprise then that the Lumière brothers, owners of the patent for the Cinematograph, chose a train as the subject of their ground-breaking 50 second short film Arrival of a Train at La Ciotat ( L'arivee d'un train en gare de La Ciotat) as early as 1895 .

In Japan, filmmakers such as Mizoguchi Kenji and Ozu Yasujirō used railway imagery to symbolize Japan's rapid modernization and subsequent social changes, including urban migration to the petit-bourgeois suburbs from which the new lower middle classes commuted. The advancement of rail technologies in this era was used to cast Japan's aggressive expansion in a positive, modernizing light. For example, the South China Rail system was promoted to justify Japanese soldiers' presence in the region, culminating in the formation of Manchukuo, the Imperial Japanese puppet state. After Japan's defeat in 1945 however, train imagery began to take on new 
meanings as the railway became associated with the horrors perpetrated during Japan's Imperial expansion and in prisoner of war camps (Piccigallo 1979: 113).

For much of the twentieth century then, railway imagery on-screen was associated with social and political change in Japan, from the 1920s and 1930s modernization era, through the militarization of the late ' 30 s and 1940 s, to the upheaval of defeat and occupation in the ' 40 s and early 1950s. In this sense, trains on film can be read in terms of a Japanese national identity in flux; railways symbolized progress and modernity as Japan strove to be recognized as a developed nation and member of the global community in the aftermath of the modernizing, Westernizing influence of the Meiji era. Expanding railway infrastructure across the colonies in the 1930s and 1940s displayed Japan's increasing technological and military prowess until defeat in 1945, after which Japan's poverty and new distaste for militarism was symbolized by overcrowded trains full of starving ragged travellers refusing to vacate seats for uniformed repatriates (as shown in Kinoshita Keisuke's Tragedy of Japan/ Nihon no higeki, Shōchiku, 1953). Whatever the direction of social change in twentieth century Japan, there was a railway anecdote or train metaphor to match.

In contemporary Japanese cinema, the Yamanote line in particular symbolizes the confluence of modernity, technology, possibility, and historical trauma that shadows the struggle to construct a coherent sense of postwar Japanese national identity. The circular construction of the line constitutes a blockage in the context of the historical design of Japanese cities to favour flow (Huang 1995; Taggart Murphy 2014: 10), and so the Yamanote line becomes a static holding space in which film protagonists contemplate and work through personal challenges or traumas. From the art-house to the blockbuster, recent films have employed the Yamanote line as a metaphor for blockage and transformation. Hou's Café Lumière (whose title links the 
cinema with the railway in a reference to the Lumière brothers) features a young woman considering her unplanned pregnancy on the Yamanote line, while the Korean-Japanese production 26 Years uses the space to depict a Korean student coming to terms with Korean-Japanese history.

Hou's use of the Yamanote line is unsurprising in the context of his earlier films set in Taiwan, in which trains feature frequently. The Lumière brothers' early films are even recreated in Dust in the Wind (Lian lian feng chen, Hou Hsiao-Hsien, Central Motion Pictures, 1987), which visually references both Arrival of a Train at La Ciotat and Passage Through a Railway Tunnel (Hasumi 2008: 184). However, the Yamanote line was not an obvious choice for the setting of Café Lumière. Protagonist Yōko is based on the director's friend, a Taiwanese woman living in Tokyo and working as a freelance writer. In developing the character, Hou emphasized the importance of environment, and specifically train lines; 'I did more research on the layout of Tokyo, trying to figure out which part of Tokyo, and on which railway line, people like my characters usually lived' (Hou 2008: 181, trans. Liu). While selfemployed workers like Yōko appeared to live along the Chuo main line and ChuoSobu line, Hou was strongly attracted to a house in Zōshigaya, near Kishibojin, as the perfect location for Yōko's home. (It is not clear whether Hou's decision to set Yōko's home near Kishibojin temple was influenced by the legend of the Kishibojin goddess, a demon woman who ate children, before converting to Buddhism and becoming the protector of pregnancies and expecting mothers.) This area is primarily serviced by the Arakawa tram, a small streetcar that lends a nostalgic calm to travel through this central area of Tokyo near Waseda University. However Yōko is only briefly shown travelling on the Arakawa line before connecting to the Yamanote for the larger part of her travel throughout the film. Most of the shots from within trains 
and from outside trains focus on the Yamanote line, which connects to the Arakawa line through Ōtsuka station. The striking point here is Hou's seemingly spontaneous association of the process of developing a film character with establishing which railway line the character will use. Yōko's character would perhaps have been different had she lived on the Chuo line after all, however the socio-political and historical connotations of the Yamanote line confer a particular atmosphere on the characters who travel within its loop.

Selecting the setting for Hanadō Junji's 26 Years Diary was a more straightforward process, in that the film is based on a real-life event that occurred on the Yamanote line. This semi-fictional account follows the life of Lee Su-Hyon, a Korean student killed in a high profile accident on January 26, 2001. Lee and a Japanese photographer, Sekine Shirō, were run down by a Yamanote train while attempting to rescue Sakamoto Seikō from the rail track in Shin-Ōkubo station (Ogawa 2008: 1). Lee was subsequently cast as a kind of martyr to Japan-Korean relations by Japanese and Korean politicians alike, who interpreted his selfless act as a symbol of hope for the two nation's shared futures (Takei 2011; Kyodo News 2007). However Hanadō's romanticized account of Lee's short life does not fail to mention his difficulties as a Korean student, using a variety of sites along the Yamanote line to draw out the problems facing Koreans in Japan as well as the opportunities Tokyo can offer.

\section{The Yamanote Line as International Space}

The Yamanote line is an explicitly international space in these two films, in which human relationships allegorize Japan's relation to its ex-colonies. Commuters stop for Korean food in Shin-Ōkubo, or Chinese in Ikebukuro, while Ameya-yōkocho in 
Ueno still carries the connotations of Americanization implied by the name, a reference to the American goods available in the Occupation-era black-markets under the train lines. The Yamanote line encloses these spaces in the heart of Tokyo, but also connects to the wider world through Haneda airport via Hamamatsuchō station, and to the rest of Japan by Shinkansen or rural train services from Tokyo and Shinagawa stations. Material cultural exchange is facilitated by the variety of international spaces the circular track passes through. On film, the enclosed line becomes a metaphor for Japan's engagement with its international neighbours within its own domestic sphere, as well as a space in which protagonists consider solutions to problems at once personal, cultural, political, and national.

Hou privileges the environmental sounds of Tokyo and the surrounding countryside over dialogue in his quiet film, and so the Yamanote line suggests the characters' mental states. Yōko, played by singer Hitoto Yō, has conceived a child while overseas in Taiwan, and her travel on the Yamanote line becomes an opportunity to think through her options for the future. Passing through the Chinese spaces of Ikebukuro and the Korean spaces of Shin-Ōkubo, Yōko's travel path hints at some of the issues involved in her pregnancy; a potential international marriage to a man from Japan's former colony, and perhaps a move to a foreign country where Yōko will be an immigrant much like the non-Japanese residents of Ikebukuro and Shin-Ōkubo. For viewers who associate the Yamanote line with the spectre of Sugamo prison, once located in Ikebukuro, the historical tensions between Japan and Taiwan in the wake of war and colonisation also come to bear on Yōko's difficult decision.

Yōko is both wary of her welcome in Taiwan, as a Japanese woman, and fearful of being colonised herself; she describes to her stepmother the demanding 
character of her partner's mother, and her insistence on bringing her into the family business. The shifting distinctions between Japanese and other East Asian national identities is mirrored in the star persona of Hitoto, born to a Taiwanese father and Japanese mother, and in her character's research on Taiwanese composer Jiang WenYe (1910-1983), who left his Japanese wife to teach in occupied China (1938). Jiang's life mirrors Yōko's situation in that the Taiwanese father of her child has moved to Thailand and she must decide whether to join him. The international spaces that the Yamanote line passes through as Yōko considers her options suggest a degree of blurring between Japan and the rest of East Asia, mirrored in the lives of the characters.

There is some reference to class division also, as Yōko is a freelance writer and researcher in middle class urban Tokyo, while her partner's family make umbrellas in Taiwan, Thailand, and China. This division echoes the separation of the Yamanote areas from the shitamachi in pre-war films such as Ozu Yasujirō's, where 'Yamanote' denoted the uptown spaces of the moneyed classes as distinct from the downtown and suburban areas of the working and lower middle class. The literary histories of the areas Yōko visits for research, including her friend Hajime's bookstore in Jimbochō, connecting through Ochanomizu station, and Tomaru Bookshop in Kōenji posit her life in Tokyo as academic and aspirational by contrast with the unnamed factory areas of Taiwan, Thailand, and China. Here the use of the Yamanote line as a setting for Yōko's decision-making mirrors the pre-war distinction between 'Yamanote' films, or elegant stories about bourgeois characters, and the shitamachi narratives of struggle and hardship (Satō 1988: 8). While the Yamanote line encompasses the old upper class Yamanote area, it also passes through newer working class areas such as Sugamo (see Coates this issue) and embedded 
working class areas in the shitamachi. Yōko's travel juxtaposes the elite educated life she currently lives with the prospect of her future as a family member of a Taiwanese labouring family. Yōko regularly uses the Yamanote line to return to her Japanese family and hometown, transferring through the working-class textile production area of Nippori station to Yoshii station in Gunma prefecture on the way to her father's large house in the country. The international Yamanote line propels her further into the heart of Japan rather than out to its neighboring areas, suggesting the path she will choose at the end of the film.

Though a blockbuster of a very different tone, 26 Years Diary uses the Yamanote line in a similar manner. The Korean protagonist Lee Su-Hyon, played by Lee Tae-Sung, uses the Yamanote line to travel between his Japanese language classes and his job packing Lotte chocolate in Shin-Ōkubo, as suggested by aerial shots of the Yamanote line inserted in between school and work scenes, and repeated shots of the Shin-Ōkubo station sign. Unlike Yōko, Su-Hyon is never shown on the train itself, more often bicycling to the open-air music venues of Shibuya. Here he meets Yuri, played by singer Mākii, and encourages her to follow her dreams while standing up to her racist father. While Shibuya is depicted as an idyllic dream space of love and musical collaboration, the areas around the train station are presented as dangerous spaces where Su-Hyon is the victim of physical assaults and a racist hitand-run. His disillusionment with the treatment of Koreans in Japan sends him back to Korea, where his parents advise him not to let the recent history of Japanese Korean relations distract him from the opportunities Japan can offer. Su-Hyon returns to Japan and develops a hit song with his girlfriend, but before he can see her perform a train runs him down on the Yamanote line while he attempts to rescue a commuter. In Hanado's romantic interpretation of a real-life incident, the Yamanote line features 
as a space to work out issues connected to Japan's military past and its impact on the lives of Korean migrants, as well as a showcase for the best and worst Tokyo has to offer, both in terms of everyday life and as a means to follow one's dreams.

The Korean space of Shin-Ōkubo where Su-Hyon works begins to blur into the music and play spaces of Shibuya towards the end of the narrative, as Yuri's racist musician father suddenly reveals his capacity to speak fluent Korean. Drawing from an earlier scene in which Su-Hyon and Yuri travel to Osaka to meet a zainichi Korean relative, Shota Ogawa has suggested that this may imply that Yuri and her father have some Korean heritage. The Osaka scene opens with a shot of a nameplate showing both Japanese and Korean surnames, referring to the tendency to take a 'Japanized' name in order to blend in or hide Korean origins (Ogawa 2008: 7). Could Yuri's father be a 'self-hating' zainichi Korean, as Ogawa suggests? In this potential sub-plot, the blurring function of the Yamanote line is mirrored in character development, depicting Tokyo as a site of ambiguous ethnic identities rather than a space in which ethnicities are clearly marked, as might be imagined in the separation of 'Korea town' and Chinatowns from the 'Japanese' spaces of the city. The Yamanote line connects these areas, blurring their distinctions by allowing protagonists to pass through and mix a variety of ethnicized areas into their daily lives.

\section{'Outside Over There': The Yamanote Line as Demarcation}

Café Lumiere was commissioned by Shōchiku studios to commemorate the centenary of Ozu's birth. While the trains in Ozu's films symbolize movement into and out of the city, from the safe spaces of home to the competitive spaces of urban working life, Hou depicts the Yamanote line as a safe space, despite the dangerous or exotic 
reputations of some of the areas the line passes through. Yōko often falls asleep on the train, suggesting she is comfortable within its space. Hou emphasises the gentle rocking motion of the carriage; Yōko tends to travel during the day, and so the train is less packed and the pushing and bumping many commuters experience is noticeably absent. Instead, the train is a place for quiet contemplation, and a link between Yōko and her friend and potential love interest Hajime. Trains often foster such intimate romantic relationships in Hou's work, replacing dialogue with the visual image of two bodies swaying together in the rhythm of a moving train (Hasumi 2008). An early scene showing Yōko and Hajime passing in separate trains moving in the same direction creates a sense of the fateful nature of their relationship. The characters observe one another, but do not call out or rush to meet; as the Yamanote line is circular we know their paths will cross again in time.

Hou's Yamanote line is thereby positioned as a comforting space, a kind of womb in which the protagonists are incubated. This theme is underscored in a scene in which Hajime visits Yōko as she recovers from illness. He brings a series of computer-generated artworks showing green trains surrounding a foetus; the Yamanote line becomes a kind of womb for a foetus version of himself, though the parallels with Yōko's unborn child are clear. The line creates an incubation space for Hajime's alter ego, but there is also an air of loneliness about the image, as both Yōko and Hajime agree on a sense of isolation perceptible in the figure's eye. When Yōko is isolated by illness and indecision about her future, Hajime brings her his Yamanote artwork to soothe her, just as the Yamanote line platform is the space she uses to wait for her feelings of sickness to pass as she travels to meet him, and the Yamanote Yurakuchō station is the location where she casually reveals her pregnancy. 
The idea of the Yamanote line as a space of 'iyashi kanji' or a space to soothe the soul is a common trope in the literature of Murakami Haruki, whose characters ride or observe the line when confronted with feelings of isolation, and with difficult decisions. Creta Kano rides the Yamanote line in circles while exploring her feelings of numbness after a sexual assault in The Wind-Up Bird Chronicles (1995), while the unnamed narrator of $A$ Slow Boat to China finds his Yamanote trip prompting feelings of isolation as he considers the historical relationship between China and Japan (2004). Colourless Tsukuru Tazaki and His Years of Pilgrimage (2013) connects these themes of isolation, iyashi, and problem solving most clearly.

So, where should I go?

There was really only one choice.

He walked along the main street to Tokyo Station, passed through the Yaesu entrance, and sat down on a bench on the Yamanote line platform. He spent over an hour watching as, almost every minute, another line of green train cars pulled up to the platform, disembarking hordes of people and hurriedly swallowing up countless more. The view didn't soothe the pain in his heart, but the endless repetition enthralled him as always and, at the very least, numbed his sense of time. (Murakami 2013: 124-125)

Repetition seems to be a major component of the comforting nature of the Yamanote line for both Murakami and Hou's protagonists. Being part of a mass of people also seems cathartic for characters contemplating alienation; Tsukuru Tazaki considers his estrangement from his group of school friends and inability to make a real connection with his lover, Creta Kano interprets her rape as an event which casts her outside the common social sphere, and the protagonist of Slow Boat to China 
considers the isolation of Chinese residents in Tokyo alongside his own feelings of isolation. The opportunity to be 'alone together' (see Nishimura-Galbraith, this issue) afforded by the Yamanote line appears to be attractive to protagonists facing difficult or painful decisions, who use the line to surround themselves with the comforting warmth of fellow travellers while remaining immersed in their own thoughts.

We might expect the comforting aspects of being 'alone together' to be more attractive to male characters than female characters given the long history of crowded trains as spaces of sexualized assault, as in Train Man. However neither Murakami, Hou, or Hanado make any allusion to the Yamanote line as a particularly gender-privileged space; male and female characters alike seek out the line in Murakami's fiction, and despite her pregnancy, Yōko presents herself as a gender neutral character with loose-fitting clothing, hair tucked into a hat and a slow carefree approach to romance. Perhaps the womb-like nature of the space encourages travellers within to identify as pre-gendered fetus characters, or maybe the thinking space the line provides has an element of disembodiment. In any case, while the Yamanote setting suggests issues of race and class disparity, it seems oddly degendered.

While Hou's characters, like Murakami's, display little emotional disturbance on the surface, Yōko's anxiety about her pregnancy and the decisions it requires her to make is evident in a dream she recounts to Hajime. Her story of a baby turning into a wrinkled creature made of ice suggests to him the changeling myth of European folktales, and he gives her a copy of Maurice Sendak's Outside Over There (1981), which tells a similar story. The children's book prompts a memory in which child-Yōko reads the book at a religious gathering, where her birth mother chants 
religious sutras before disappearing from her life. ${ }^{1}$ While the changeling trope suggests Yōko’s anxiety about raising a half-Japanese half-Taiwanese child, the wording of Sendak's book, read aloud by Yōko, indicates unspoken fears about the 'outside over there' space, including fears of being cast out, or being unable to return to the inside, over here. This possibility is suggested in a sub-plot in which her father refuses, or is unable, to speak to her for a time after learning of her pregnancy. If Taiwan, Thailand, and China are Yōko's 'outside over there,' the Yamanote demarcates an 'inside' space encompassing her research, her de-facto office in a local café, and the bookstore where she meets Hajime. Her home and her family are only tangentially linked to the Yamanote line, suggesting the slightly outsider nature of her relationship with her father and stepmother.

The Yamanote line is not exactly an inclusive space for Su-Hyon of 26 Years Diary; though it connects his work spaces to his play spaces, his work space is explicitly marked as a Korean in clear introductory shots of the Yamanote ShinŌkubo station sign at the beginning of each work scene. He often bicycles to Shibuya, where he is regularly reminded that Shibuya and Harajuku's music-friendly areas are not necessarily Korean-friendly. Train travel is juxtaposed with bicycle and pedestrian travel to position the Yamanote line as a slightly threatening space. The run-down but welcoming Osaka ward of Ikuno, where Su-Hyon meets a zainichi

\footnotetext{
${ }^{1}$ Hou's film and Sendak's story have some unusual similarities with Murakami's work; Sendak's main character Ida finds herself trapped 'outside over there' because she climbs out of a window backwards rather than forwards. Descending an emergency staircase backwards, Murakami's character Aomame similarly finds herself in a parallel universe in $1 Q 84$ (2011). Hou's depiction of Yōko abandoned by a religious mother at a cult-like gathering chimes with Murakami's story of a young girl abandoned by her cult-leader parents in the same novel. Meanwhile the changeling theme introduced by Yōko's dream and central to Sendak's story is echoed in the myth of the Kishibojin goddess, from whose shrine Yōko's neighbourhood takes its name. Before converting to Buddhism and becoming the protector of unborn children, Kishibojin was a demon who kidnapped children to eat, or to feed to her own brood, estimated between 100 and 500 according to various iterations of the story, which was translated from the original Indian myth to Japanese Nichiren sect Buddhist traditions in the Kamakura period.
} 
Korean relative, is accessed by bicycle, and a series of sun-lit idyllic shots of Yuri and Su-Hyon playing in the natural spaces of beaches and forests comprise their bicycle trip from Osaka to Tokyo. In fact the only scene in which Su-Hyon is shown on a train platform, and the first time we see him attempt to travel to Shibuya by train rather than by bicycle, concludes with his death. In many ways, Su-Hyon's attempt to save the Japanese commuter who falls on the tracks at Shin-Ōkubo is a means of claiming the Yamanote line as his own space, in which he assumes a responsibility for others. This attempt ultimately fails on the personal level, as Su-Hyon dies, though perhaps something is achieved at the symbolic level as his sacrifice for a Japanese commuter elides racial difference and emphasizes a shared humanity.

Hanadō's film uses the Yamanote line to symbolize the exciting opportunities Su-Hyon recognizes in Tokyo, from the glamour and hope of the music world of Shibuya to the moneymaking and promotion opportunities in his part-time work. The mobility that the Yamanote line affords even poor students creates a sense that the city is theirs to explore, even while racist encounters underscore their lack of right to the space. Freedom of movement is often conflated with hope, however the Yamanote line as film trope fuses the utopian sense of the city as open to all with the more negative sense of areas of Tokyo as clearly demarcated for use by a specific ethnicities, genders, or classes. While Yōko's freedom of movement and comfortable negotiation of Tokyo's transport system can be interpreted positively as a sign of her independence (Thornbury 2014: 61), the Yamanote line positions the aspirational and educational areas where she conducts her research against the dangerous, or threateningly 'Other' ethnic spaces on the rest of the line, allegorizing the choice she must make between interracial marriage in Thailand and continuing her life in Tokyo. The Yamanote line is almost a concrete manifestation of the pros and cons of 
moving overseas versus staying in Japan. In the end, she resolves to stay in Tokyo and raise the baby with Hajime, opting to stay within the circle demarcated by the Yamanote line rather than cross over 'outside over there'.

In both Café Lumière and 26 Years Diary, the Yamanote line is depicted as a space both safe and dangerous, connecting aspirational and exciting spaces of possibility to areas of exclusion, discrimination, or threat. Though the line connects Su-Hyon to almost all of central Tokyo, it also describes an inner geographic and economic circle from which he is excluded. And while the gentle motions of the train lull Yōko to sleep, the train crushes Su-Hyon to death. The comforting aspect of the Yamanote line on film appears to be connected to its repetition and circularity; its non-directional nature means commuters do not have to commit to a final decision and do not risk making the kind of major mistake which could take time and effort to correct. In this sense it is the perfect space for protagonists contemplating lifechanging scenarios; a kind of temporary holding space in which to focus on the problem at hand, undistracted by environmental demands. The Yamanote line on film works best as a neutral processing space, and fails protagonists who attempt directional change.

\section{Fükeiron and the Disciplining Power of Urban Space}

Hou and Hanado's use of the Yamanote line as a motif to develop character and motivate plot is almost novelistic in its similarity to Murakami's use of the symbolic space. When analysing film however, we must ask not only how plot and characterization develop, but also how the use of particular devices or tropes impact on film style. How does filming trains, or incorporating train imagery into narrative film, affect the mechanics of constructing a film, and its final appearance? 
Café Lumière was originally one of three short films planned to celebrate

Ozu's centenary, though the others were never made and Hou's expanded to feature length. Its hard not to see parallels to Ozu's favoured motifs in the references to class division, in the sparse plot centred on a potential marriage which never happens, in Yōko's costume of white blouse and dark skirt and her visit to her parents in the countryside, and in the open-ended nature of the narrative. However the style of Hou's film suggests similarities with a very different genre of Japanese cinema, the quasi-documentaries and ethno-fiction films of the late 1960s and 1970s which Yuriko Furuhata calls 'cinema of actuality' (2013). In relation to these experimental films, fükeiron discourse posited landscape as 'an antithetical relation to the dramatic, spectacular images of violence and struggle that dominated the mass media' (Furuhata 2013: 117). For example, A.K.A Serial Killer (Ryākusho: renzoku shasatsuma, Adachi Masao, 1969), first shown to the public in 1975, draws on fükeiron in using the landscapes of Abashiri, Sapporo, Hakodate, Tsugaru Plane, Tokyo, Nagoya, Kyoto, Osaka, Kōbe, and Hong Kong to convey the mental state of teen serial killer Nagayama Norio. Urban landscape in both Café Lumière and 26 Years Diary similarly draws attention away from action and gesture to a more contemplative symbolism, inviting us to speculate on Yōko's inner life and SuHyon's inevitable death, respectively.

Hou's film is not a documentary, but neither is A.K.A Serial Killer, in the sense that the real locations featured are arranged in a kind of collage over a nondiegetic soundtrack, without an explicit narrative arc or argument. The filming style of Café Lumière is in fact very similar to the filming of A.K.A Serial Killer, as Hou was unable to secure permission from Japan Railways to film on the Yamanote line. As a result, the camera crew were forced to go undercover, packing minimal 
equipment into backpacks and assembling their gear on the train (Hou 2008: 182). Hou did exercise directorial agency over particular shots; for example, the scene in which Yōko and Hajime pass in separate trains had to be shot eighteen times. Nonetheless the filming style closely mirrors that of A.K.A Serial Killer, which repeats shots of train stations and trains seen from platforms and out of train windows to create the sense of boredom and frustration that characterized Nagayama's mentality, interpreted by Adachi and Matsuda Masao as a revolt against the uniformity of the everyday environment, symbolic of the productive forces of state power (Furuhata 2013: 135).

While Nagayama is physically absent from A.K.A Serial Killer, Hou's film structures our view from the windows of the Yamanote line from Yōko's perspective, anchored by shot reverse-shot sequences between landscape and medium shots of Yōko travelling. The landscape Yōko observes is markedly different to that which Nagayama would have seen; while A.K.A Serial Killer shows the banality of both rural and urban landscape, Yōko's view is calming rather than frustrating. The parts of the city she travels through are quaint and tidy, sun-lit and clean. Her fellow commuters are observed intimately in a friendly and curious manner, with natural lighting and a quiet soundtrack creating a sense of calm. Yōko's Tokyo is an optimistic space of potential, whereas Nagayama's landscape was frustrating in its poverty, banality, and excruciating repetition. Hou's naturalistic soundtrack has the opposite effect to Adachi's unnerving free jazz, which distances the viewer from the landscape, shutting us out of the diegetic environment. By contrast, the comforting rhythm of the Yamanote line sounds, matching closely the movements of carriages and doors, seals us into Hou's mise en scène, inviting us to share the calm mood of Yōko and her fellow travellers. The repetitive landscapes around the Yamanote line 
may be filmed in the style of the actuality films of the late post-war, but their content is closer to the aspirational Yamanote areas depicted in pre-war and early post-war classical cinema.

A.K.A. Serial Killer presents landscape as always potentially threatening; Matsuda Masao, who collaborated with Adachi, recalls 'We filmed scenes of crime just like landscape' (Furuhata 2007: 351). The viewer strains to determine which landscapes are crime scenes and which are not, perpetually compelled to imagine Nagayama's victims' bodies in each new space as it appears before the camera. While shots of Yasaka shrine in Kyoto, the scene of Nagayama's second murder, are highlighted as crime scenes by a dramatic series of quick zooming shots, the other three shooting locations slip by terrifyingly undifferentiated from everyday environments. Of course, the horror lies in the fact that a crime scene is also an everyday environment; the spaces we regularly inhabit as we go about our lives can at any moment become scenes of crime or tragedy. The characters of Café Lumière flirt with this possibility when Hajime muses that his recordings of train sounds might assist a criminal investigation, "Someone might need to hear a tape as evidence of something." The small figure surrounded by trains in the center of Hajime's artwork is also surrounded by a dark colour he suggests is blood, though when Yōko assumes it is his blood, he asks why she would think his blood is so dark. Here the parallels with Yōko's mixed-race child shade into the sinister undertones of crime and blood, chiming with the dark themes of Sendak's story of child abduction. Though the plot of Hou's film is minimal, these themes keep the viewer in a degree of suspense throughout, hastening the plot and positing the quiet open ending of the film as a point of relief rather than disappointment: nothing bad has happened after all.

Conversely, 26 Years Diary begins from a point of prior knowledge of the 
tragedy of Lee Su-Hyon's death, widely publicized at the time and repeated again in promotional materials for the film. While Su-Hyon is never shown on a train or platform before the climactic scene, shots of train exteriors and stations repeat throughout the film. This may in part be due to filming difficulties similar to those experienced by Hou, or to reluctance on the part of the filmmakers or the JR company to emphasize the potential dangers of rail travel to viewers who are inevitably also commuters. The overall effect is a lessening of suspense; viewers do not await SuHyon's death but are encouraged instead to focus on the budding romance and $\mathrm{Su}-$ Hyon and Yuri's growing understanding of what life is like for Koreans in Japan today.

Fükeiron discourse made a distinction between the cinematic image and televised or newsreel imagery, celebrating cinema's ability to create a mood rather than present a didactic narrative. Furuhata argues that this quality allowed the landscape imagery of actuality films to point to invisible forces enacting on everyday life, where images of urban landscape 'index' the activity of state power by showing the constructed and controlled nature of the urban environment (2013: 170). SuHyon's growing understanding of what it means to be Korean in Japan is similarly structured around urban landscape. Learning to be Korean in Japan is a process of disciplining, structured and supported by the environment; Su-Hyon is explicitly invited to aim for success as a Korean worker in Shin-Ōkubo, but discouraged from his musical ambitions in Shibuya, the 'Japanese' music space. In the natural areas of beaches and forests he can engage in cross-cultural romance, but in the urban spaces around the Yamanote line he is physically threatened for claiming a place on the street. The hostile nature of the urban environment is apparent in the soundtrack, where the loud noise of the Yamanote trains passing cut off his halting conversations 
with Yuri. When Su-Hyon refuses to be disciplined by the landscape, fighting both racial division and his own fear to stand in front of the oncoming Yamanote train, he is killed. While the urban landscapes analysed by Furuhata present a threat to Japanese citizens as well as non-Japanese, comparing Yōko and Su-Hyon’s experiences of the Yamanote area suggests that the disciplining power of landscape is most violent towards outsiders. Yōko reads the threat of 'outside over there' and decides to stay within the boundaries of Japan and the Yamanote line. Su-Hyon is offered a safe half-life in the small slice of Tokyo that is Shin-Ōkubo as a Korean factory worker mediating between Japanese managers and Korean employees. When he resists the disciplining restriction of his urban space and his aspirations to travel to Shibuya however, he is no longer able to survive.

\section{Thinking from the Yamanote}

So what can we learn about contemporary Japan by 'thinking from the Yamanote line' on film? If we approach film as Miriam Hansen has suggested, as a 'reflexive horizon' that 'reflects, rejects, transmutes or negotiates' issues in everyday life (2000: 341-2), we can see the Yamanote line on screen as symbolic of the open question that is Japanese national identity today. In the diverse ethnic, economic, and historical spaces it traverses, the Yamanote line loops out beyond accepted interpretations of 'Japaneseness' to the fringes of national, social, and cultural identities, and then comes back again in a complete circle. In this sense, the line is a perfect metaphor for Japanese national identity, and the very concept of national identity more broadly speaking. As Judith Butler argues, we are constituted as much by what we are not (or refuse to be) as much as by what we are, or claim to be (1993: xiii). The circular structure of the Yamanote line, encompassing the historical blight of Sugamo prison, 
the migrant hubs of Shin-Ōkubo and Ikebukuro, the futuristic Harajuku and the business and commerce centres of Shinagawa and Shinjuku, as well as the hippy spaces of Shibuya and the global fringe of Hamamatsuchō, maps a looping out from a normative or widely accepted Japanese identity, to its fringes, and back again.

Protagonists and viewers alike are invited to consider what it means to be Japanese, or to be Other in Japan, using the codes of the Yamanote motif.

The Taiwanese Hou was commissioned to make Café Lumière in homage to Ozu, while 26 Years Diary was funded and filmed in both Korea and Japan. As such, neither film can be considered entirely 'Japanese'. Though similar themes of identity issues, isolation, and personal safety and development are evident in many films featuring trains directed and funded solely by Japanese creators, including Train Man and Suicide Club (Jissatsu sākuru, Sono Shion, 2002), few Japanese films refer to the Yamanote line explicitly, employing a more general use of the generic railway theme to create in-between spaces between work and leisure. As the Yamanote line is explicitly named in the films of non-Japanese directors or in Japanese-directed international co-productions then, perhaps the Yamanote line is particularly suited to exploring the more global aspects of contemporary Japanese national identity, including historical issues between Japan and its nearest East Asian neighbours. As the central ring line around the major tourist attractions in Tokyo, we can also expect the international audiences of art house festival films and international co-productions to recognize the Yamanote line more readily than the many minor rail lines crossing Japan, and so there may be an element of making everyday travel in Japan readable to outside viewers in the specific focus on the Yamanote line.

The two films analysed here can be read as outsider views of Japan, or views of Japan made for outsider audiences; however national identities are informed as 
much by a nation's global image as by its self image. The use of the Yamanote line to demarcate an insider space from 'outside over there' suggests that the trope can speak to anxieties around how Japan is imagined within East Asia, as well as how class and racial differences are handled in Japan today. The many protagonists who ride the line to soothe personal anxieties, or to find solutions to problems, use the space as a kind of visual pros and cons list, setting the positive qualities of Tokyo as a living space or Japan as a society alongside its negative aspects. The 'alone together' aspect of urban train travel similarly showcases the best and worst of contemporary urban life, as commuters derive comfort from the presence of others without engaging with the individual subjectivities of the others on the train (see Nishimura-Galbraith this issue). On the other hand, protagonists who try to enact concrete physical change on the Yamanote line tend to suffer. The Yamanote line on film seems to be a space of contemplation rather than a space of change, suggesting that attempts to interpret the line as a positive example of social change gloss over its everyday functions.

\section{Bibliography}

Butler, J. 1993. Bodies That Matter: On the Discursive Limits of Sex. New York: Routledge.

Carlin. D. 1997. The Cultural 'Traumascape': Look Both Ways, Railways Accidents and Trauma. Senses of Cinema, 45 (unpaginated). http://sensesofcinema.com/2007/australian-cinema-45/look-both-ways/\#18 Freedman, A. 2002. Commuting Gazes: Schoolgirls, Salarymen, and Electric Trains in Tokyo. The Journal of Transport History, 23 (1), 23-36.

Furukawa, Y. 2007. Returning to Actuality: Fūkeiron and the Landscape Film. Screen, 48 (3) 345-362. 
Furukawa, Y. 2013. Cinema of Actuality: Japanese Avant Garde Filmmaking in the Season of Image Politics. London: Duke University Press.

Hansen, M. 2000. The Mass Production of the Senses: Classical Cinema as

Vernacular Modernism. In: C. Gledhill and L. Williams ed. Reinventing Film Studies, London: Arnold Press, 332-350.

Hasumi, S. 2008. The Eloquence of the Taciturn: An Essay on Hou Hsiao-Hsien. Inter-Asia Cultural Studies, 9 (2), 184-194.

Higbee, W. and Lim, S. H. 2010. Concepts of Transnational Cinema: Towards a Critical Transnationalism in Film Studies. Transnational Cinemas 1 (1), 7-21.

Hou H. 2008. Cinema and History: Critical Reflections; Hou Hsiao-Hsien. Trans. Liu, P. Inter-Asia Cultural Studies, 9 (2), 173-183.

Huang, Y and Honda, S. 1995. Site Selection and Planning of The Center Lines of Ancient Japanese Imperial Capitals: Feng-Shui Thought and Ancient Capitals' City Planning. Journal of Architecture and Planning 474, 143-150.

Jacobowitz, F. 2005. Hou Hsiao-Hsien's Cafe Lumiere. CineAction, Winter.

Kinema Junpo. 2007. Hanaoka Junji Kantoku Intabyu. Kinema Junpo 1475, January, p. 60 .

Kirby, L. 1997. Parallel Tracks: The Railroad and Silent Cinema. Durham: Duke University Press.

Kwai-Cheung, L. 2004. Return to What One Imagines to Be There: Masculinity and Racial Otherness in Haruki Murakami's Writings about China. Novel: A Forum on Fiction, 37 (3), 258-276.

Kyodo News. 2007. Film Tribute Debuts on Korean in Failed Rescue. Japan Times January 27. http://www.japantimes.co.jp/news/2007/01/27/national/film-tributedebuts-on-korean-in-failed-rescue/\#.VrREKFLp8y4 
Murakami H. 1995. The Wind-Up Bird Chronicle: A Novel. Trans. J. Rubin, London: Vintage International.

Murakami H. 2011. 1Q84. London: Harvill Secker.

Murakami H. 2014. Colourless Tsukuru Tazaki and His Years of Pilgrimage.

London: Harvill Secker.

Needham, G. 2006. Ozu and the Colonial Encounter in Hou Hsiao-Hsien. In: D.

Eleftheriotis ed. Asian Cinemas: A Reader and Guide. Honolulu: University of Hawaii Press, 369-383.

Ogawa, S. 2008. 26 Years Diary: Issue of Cultural Essentialism in "Multicultural" Japan. In: 2nd Global Conference - Multiculturalism, Conflict and Belonging, 3-6 September 2008, Mansfield College, Oxford.

Ogawa, S. 2009. Hou Hsiao-Hsien in Japan: From Taiwan Trilogy to Café Lumiere.

In: J. Gimenez ed., Asian Connection. Lyon, France: Asiexpo Edition, 150-161.

Ozawa-de Silva, C. 2010. Shared Death: Self, Sociality and Internet Group Suicide in Japan. Transcultural Psychiatry, 47(3), 392-418.

Piccigallo, P. 1979. The Japanese On Trial: Allied War Crimes Operations in the East, 1945-1951. Austin: University of Texas Press.

Satō, T. 1988. Tokyo on Film. East-West 2:2 (June) 1-12.

Schivelbusch, W. 1986. The Railway Journey: The Industrialization of Time and Space in the 19th Century. Berkeley and Los Angeles: University of California Press. Sendak, M. 1981. Outside Over There. London: Harper-Collins.

Shu-Yeng Chung, S. 2013. Framing Modern Japanese Domestic Interiors through Cinematic Mapping. In: Asian Conference on Arts and Humanities Conference Proceedings, 5-8 April 2012. Osaka, Japan. IAFOR, 581-595. 
Taggart Murphy, R. 2014. Japan and the Shackles of the Past. Oxford: Oxford University Press.

Takei H. 2011. Ten Years Since the Shin-Ōkubo Station Tragedy: Memorial for a Korean Exchange Student (Shinōkubo eki no higeki kara jūnen: kankokujin ryūgakusei seirashinobukai). Asahi shinbun January 23. http://www.asahi.com/special/080804/TKY201101230100.html

Thornbury, B. 2014. Tokyo, Gender and Mobility: Tracking Fictional Characters on Real Monorails, Trains, Subways, and Trams. Journal of Urban Cultural Studies, 1 (1), 43-64.

Wu, I. 2008. Remapping Ozu's Tokyo? The Interplay between History and Memory in Hou Hsiao-hsien's Café Lumière. Asian Cinema, 19 (1), 172-181.

Yiu, A. 2006. Tokyo and Beyond: Reading Japan from the Metropolis. Japan Forum 18(3), 291-293.

\section{Filmography}

26 Years Diary/ Anata o wasurenai, dir. Hanadō Junji, Sony Pictures, 2007

A.K.A Serial Killer/ Ryākusho: renzoku shasatsuma, dir. Adachi Masao et al., 1969 (screened 1975)

Arrival of a Train at La Ciotat/ L'arivee d'un train en gare de La Ciotat, dir. Auguste Lumière and Louis Lumière, Lumière Productions, 1895

Café Lumière/ Kōhi jikō, dir. Hou Hsiao-Hsien, Shōchiku, 2005

Dust in the Wind/ Lian lian feng chen, dir. Hou Hsiao-Hsien, Central Motion Pictures, 1987

Lost in Translation, dir. Sofia Coppola, Focus Features, 2003

Passage Through a Railway Tunnel/ Passage d'un tunnel en chemin defer, dir. Auguste Lumière and Louis Lumière, Lumière Productions, 1906 
Suicide Club/ Jissatsu sākuru, dir. Sono Shion, Omega Project, 2002

Train Man/ Densha otoko, dir. Murakami Shosuke, Tōhō, 2005 